\title{
Water Finance Assessment in Drinking Water Supply System
}

\author{
Dr. Anjay Kumar Mishra*
}

Associate Professor, Madan Bhandari Memorial Academy and Pokhara University and Research Coordinator at United Technical College, Chitwan, Nepal

DOI: $10.36348 /$ SJEF.2019.v03i09.003

| Received: 05.08.2019| Accepted: 23.08.2019| Published: 25.09.2019

*Corresponding author: Dr. Anjay Kumar Mishra

\section{Abstract}

Most of the water supply systems are managed by water supply users committee. The water supply system of Dhankuta 7, 8, 9 was running 23 years. The overall objective of the study was to assess the financial Performance of Dhankuta 7, 8, 9 Water Supply System. Published report, journals, research paper, article, progress report were reviewed for secondary data as well as key informant interview was done for primary data. The financial performance was analyzed through Water Accounting System, Non-Revenue Water, Average Tariff, Personnel Cost, Unit Production Cost, Operating Ratio, Accounts receivable equivalent, Revenue collection efficiency, Cash balance of five fiscal year and Payback period. The financial performance result shows that there is dissimilarity in tariff on water accounting system, NRW is $62.31 \%$, average tariff is $\mathrm{NRs} 8.46 / \mathrm{m}^{3}$, personnel cost is $65.88 \%$, unit production cost is NRs 6.41 per 1000 litre, operating ratio is 5.8, accounts receivable equivalent is 1.02 months, revenue collection efficiency is $73.24 \%$, five continuous year is generating positive cash flow and the payback period for construction of reservoirs including $\mathrm{O} \& \mathrm{M}$ cost were 3 year half month, 2 year 7 month and 3 year 4 month for 15\% NRW, 0\% NRW and for National Average 21.6\% NRW respectively.

Keywords: Water accounting, cash balance, revenue, cost.

Copyright @ 2019: This is an open-access article distributed under the terms of the Creative Commons Attribution license which permits unrestricted use, distribution, and reproduction in any medium for non-commercial use (NonCommercial, or CC-BY-NC) provided the original author and source are credited.

\section{INTRODUCTION}

Water is one of scared public goods. Nepal is said to be high potential of water resource. It is also claimed due to lack of capital water is not managed here. Safe drinking water is one of the most basic human needs. Access to water and sanitation plays a crucial role in the overall social and economic development of a community. Provision of Water supply facilities is still a major concern for the Government of Nepal. From the past several years various government and non-government organizations have been implementing rural water supply schemes for providing community accessible to safe drinking water. There are various organizations involved in this sector. Some major organizations are Department of Water Supply and Sewerage (DWSS), Rural Water Supply and Sanitation Fund Development Board (RWSSFDB), Department of Local Infrastructure Development and Agricultural Road (DoLIDAR). There are numbers of NGO's and INGO'S involved in this sector too (RWSSP,2004). The accounting has not been practiced yet in Nepal. Dhankuta 7, 8, 9 water supply system was constructed in 1993 and then after it was being operated by Water Supply Users Committee. So Dhankuta water supply project which is the oldest project in Dhankuta town done by British Government to meet the water demand of ward no $8 \& 9$. Now the spring source both lukma khola \& chiuribote are dried up and for 7,8 \& 9 wards only single source Ghatte Khola located at ward no. 1 of Dhankuta Municipality is being used. So it is named as Dhankuta 7, 8, 9 water supply system is majour sorce of drinking water is selected for study.

This study helps to identify the financial capacity of Dhankuta 7, 8, 9 water supply users committee. It is beneficial to identify the implementation status of business plan of the system. This helps to make the water supply system sustainable. The policy makers get the information for making or revising policy for similar nature of project.

\section{Research Objectives}

The overall objective of this research is to assess the financial performance of Dhankuta 7, 8, 9 water supply systems

\section{LITERATURE REVIEW}

Water Supply Management Board Act, 2063 (2006)

The Water Supply Management Board is established on making proper and effective provisions 
in order to provide, or cause to be provided, reliable water supply and sanitation services to the residents of the municipal areas with regular managed, qualitative and easily availability. The functions, duties and powers of the Board, in addition to the functions, duties and powers set forth elsewhere in this Act, are as follows:

- To acquire, build, expand, reform and rehabilitate the service system, or cause to do so,

- To formulate and implement, or cause to be implemented, policies on the use of the service,

- To prevent the misuse of potable water and prevent pollution of potable water,

- To carry out, or cause to be carried out, study, research and survey on the source, distribution of potable water, and sanitation,

- To formulate and implement, or cause to be implemented, shortterm and long-term policies on the service system,

- To ascertain such investment as required for the operation of the service and prepare a plan for the same, and arrange, or cause to be arranged, financial resources,

- To identify the source of funding required for the expansion and development of the service and acquire the same,

- To have the rate of tariff of the service fixed pursuant to the prevailing laws,

- To make necessary arrangements for the provision of qualitative and effective service,

- To give license to the service providers for providing the service, or provide the service by entering into an agreement with the service providers,

- To recover, or cause to be recovered, the fixed tariff in consideration for the service provided to the users,

- If any user is aggrieved while providing the service by the service provider, to hear the grievance and provide appropriate remedy,

- To perform such other functions as prescribed as may be required for the operation of the service.

\section{Rural Water Supply and Sanitation Fund Development Board (RWSSFDB), 2007}

The Rural Water Supply and Sanitation Fund Development Board (the Board) was established on March 14, 1996 by Government of Nepal (GoN) through Formation Order under the Development.

Board Act, 1956, based on the studies and findings of a field-tested pilot project known as JAKPAS (Janta Ko Khanepani Tatha Sarsafai Karyakarm or People's Drinking Water Supply and Sanitation Program). Preparation studies for the pilot project were carried out with funding by the United Nations Development Program (UNDP) and a grant from Japanese Grant Facility (JGF) and executed by the World Bank/IDA for a period of three years during 1993-96. The Board was established in order to bring about fundamental changes in the conventional supplyoriented approach to adopting a demand driven and participatory development approach in rural water supply and sanitation delivery mechanism in the country.

The major objective of the board is to promote sustainable and cost effective demand-led rural water supply and sanitation services in facilitation of Nongovernmental and Private Organizations with full emphasis on community ownership in conformity with the Government's Eighth Plan (1992-97), Ninth Plan (1997-2002) and Tenth Plan (2002-2007) sector policies, which aimed at fundamental changes in rural water supply and sanitation service delivery mechanism in the country. The Ministry of Water Supply and Sanitation is the line ministry for the Board.

Rural Water Supply and Sanitation Fund Development Board (RWSSFDB) is promoting demand-driven community based approach in water supply and sanitation sector in Nepal by mobilizing non-governmental and private sector organizations in assisting communities to implement water supply and sanitation schemes. The Board has been implementing a demand driven community based Rural Water Supply and Sanitation Projects to promote cost-effective and sustainable development. The focus of the Project is to empower rural communities in service delivery with full emphasis on community ownership and responsibility in conformity with GoN's RWSS sector policy. Participatory development process in all stages of the project cycle including operation and maintenance has been adopted and recognized. Emphasis has also been accorded to community mobilization throughout the Development and Implementation phases, to awareness creation and to increasing the role of women, IP, Dalit and disadvantaged people in decision-making process health, hygiene and sanitation and income and employment generation. Overall management of the Project is done by the community. The Board allocates resources through its partners known as Support Organizations (SOs) that are national/ international nongovernmental organizations, private sector firms and community-based organizations. Consultancy firms known as Service Agencies (SAs), hired by the Board, are utilized to assist in providing technical, institutional and operational support to both SOs and communities in various stages of the project cycle. Thus, the Board has promoted public private partnership model in programmer implementation.

The major objective of the board is to promote sustainable and cost effective demand-led rural water supply and sanitation services in facilitation of Nongovernmental and Private Organizations with full emphasis on community ownership in conformity with the Government's Eighth Plan (1992-97), Ninth Plan (1997-2002) and Tenth Plan (2002-2007) sector 
policies, which aimed at fundamental changes in rural water supply and sanitation service delivery mechanism in the country. The Ministry of Water Supply and Sanitation is the line ministry for the Board. Rural Water Supply and Sanitation Fund Development Board (RWSSFDB) is promoting demand-driven community based approach in water supply and sanitation sector in Nepal by mobilizing non-governmental and private sector organizations in assisting communities to implement water supply and sanitation schemes

\section{Declaration of National WASHES Summit, 2012}

The first national summit on drinking water and sanitation concluded on Tuesday with a Kathmandu Declaration urging the concerned actors to work together to achieve the national target of universal access to sanitation by 2017.The two-day meet was jointly organised by the Federation of Water and Sanitation Users' Nepal (FEDWASUN) and various government, non-governmental and donor agencies working in the sector. The declaration stresses the need to work together and strengthen the coordination in areas such as participatory policy-making, capacity enhancement of the sanitation user groups, institutional development of FEDWASUN, and implementation of the programmes and services through the users' network. Promotion of social campaigns on sanitation and cleanliness, and documentation of vital achievements in the sector are among other priorities of the declaration.

According to the statistics provided by the Department of Water Supply and Sewerage (DWSS) under the Ministry of Physical Planning and Works in 2010, still around 57 percent of the total population is deprived of basic sanitation facilities and around 20 percent people lack access to safe drinking water. A majority of the existing water supply infrastructure is either dysfunctional or lacks proper repair and maintenance.

The drinking water and sanitation users' committees, Federation of Drinking Water and Sanitation Users' Committees, stakeholder agencies of the Government of Nepal (GoN), and national and international development partner organizations, taking a collective vow to meet the National Target for Drinking Water and Sanitation 2017, promulgate the Kathmandu Declaration at the National Summit on Drinking Water, Sanitation and Hygiene (August 6-7, 2012) and did following commitment to implement it.

- Participatory Policy Formulation, Review, Revision and Implementation

- Institutional Development and Strengthening of Drinking Water and Sanitation Users' Associations and Federation

- Operation, service expansion and upgrading of plan through users' associations and network
- Promotion of social campaign on sanitation and hygiene

- Ensuring of gender, inclusive and equitable participation and resources

- Documentation of important accomplishments

\section{Directives on operation of Water Supply Services, 2012}

It has become expedient to make the drinking water supply service delivery high quality, reliable and accessible for all by maintaining standard, regularity, transparency and accountability in the operation of such services through monitoring, assessment, supervision, regulation and coordination of the water supply services operated by water supply service providers.

As per directives the Department of Water Supply and Sewerage shall issue necessary instructions and recommendations to service providers based on its inspection, monitoring, assessment and supervision of their work in relation to operation of drinking water service and also coordinate their work and activities, as necessary. Every service provider shall mandatorily conduct periodic elections of the Executive Committee within the period stipulated in its constitution and send information about it to the Department within thirty days of such elections and if it is found during an inspection of the service provider that the past executive committee has been functioning even after the end of its tenure, without the service provider conducting elections referred to in subsection 1, the Department may lay down a period and issue an instruction to such a service provider to hold elections by that period and it shall be the duty of the service provider to abide by the Department's instruction to conduct elections as per subsection (2). Similarly every service provider shall mandatorily get its financial transactions audited annually as stipulated in its constitution. The service provider shall get the report of the annual audit endorsed by the general assembly as stipulated in subsection (1) and send a copy of the report to the Department within thirty days of its being endorsed and the Department may specify a period and issue an instruction to a service provider who has not got auditing done within the specified period as per this section to get auditing done by that period.

The service provider shall manage and protect all kinds of property associated with the drinking water supply system for that purpose and it is required to obtain prior approval of the Government of Nepal for selling or transferring the property used in the water supply system but if the service provider is found to have acted in a manner in contravention of subsection (2), the Department may issue necessary instructions for rectifying it.

The service provider may modify, alter or expand the structures of the drinking water supply system, including the approved design, map and site, 
only with prior approval of the Department and any association, organization or agency that wishes to expand the structure of the water supply system other than those mentioned in subsection (1) shall obtain prior approval of the Department. The service provider should furnish information on the tariff and installation fees collected from consumers in lieu of making available drinking water service to the Department but if the Department deems substantive changes in the tariff and installation fee obtained in accordance with subsection (1) necessary, it may issue a direction to the service provider concerned for revision.

The Department may monitor and inspect the work and activities of the service provider and issue necessary instructions at any point of time. Such monitoring and inspection shall be mandatory at least once a year. The Department may scrutinize the documents related to financial and administrative activities while carrying out monitoring and inspection stipulated in subsection (1). If the Department finds any irregularity being committed while carrying out monitoring and inspection referred to in subsection (2), it may issue an instruction to rectify the error based on the gravity of the subject-matter. (4) It is the duty of the Service Provider to furnish the details requested by the Department during the process of monitoring and inspection as per this clause.

Every service providing organization shall be duly registered with an agency concerned in accordance with the law. A service providing institution registered in accordance with subsection (1) shall be renewed as per a prevalent law. The Department may issue an instruction to a service providing institution that has been operating the services without being registered as stipulated in subsection (1) or renewed as stipulated in subsection (2) to register or renew within thirty days. The Department may write to the agency concerned recommending necessary action as per law against a service providing institution that has not been registered or renewed within the specified period determined by it as stipulated in subsection (3).

While making available drinking water services, the service provider must ensure equal opportunities to avail of water supply services for all without any discrimination on any ground, whether caste, religion, race, sex or political affiliation. If any service provider is found not according equal treatment while making available its water supply services, in contravention of subsection (1), the Department may issue an instruction to the service provider concerned to make available drinking water to all in an equal manner without any bias it shall be the duty of the service provider to abide by the instruction of the Department issued under subsection (2).

The access of deprived groups to the drinking water services of the service provider shall be ensured.
The service provider shall fix appropriate tariff for such deprived groups which they are able to pay in order to ensure their access as stipulated in subsection (1). The Department may carry out monitoring to ensure access of deprived groups to the drinking water made available by the service provider. If the Department, in its monitoring, finds that access of deprived groups to the drinking water services extended by the service provider has not been ensured, it may issue an instruction to the service provider concerned to make drinking water services easily available for such classes. Every service provider shall submit an annual report, describing all activities, with updated particulars, to the Department within sixty days of the end of the fiscal year in the format specified by the Department. The annual report referred to in subsection (1) shall contain, among other things, the following subjects:

- Number of consumers

- Tariff

- Sanitation status within the geographical area of the water supply system

- Detailed description of income and expenditures

- Minutes of the Annual General Assembly

- Condition of the structures related to the water supply system

- Description of alterations, modifications or expansion, if any, in the structures related to the drinking water system

- Condition of repair and maintenance of the drinking water system

- Issues of the instructions issued by the Department from time to time for incorporation in the annual report.

The Department may ask the service provider to submit periodic reports from time to time. The Department may notify the stakeholders concerned about the instructions issued by it to the service provider in accordance with this Directive through the mass media. If any provision of this Directives is found to be inconsistent with any prevalent law, the provision of the prevalent law shall prevail to the extent it is inconsistent. The Department may formulate a procedural guideline and enforce it, as necessary, in order to implement this Directive. The Department may delegate authority to its subordinate office to exercise, or abide by, all or any of the functions, duties and rights acquired by it.

\section{Water Tariff Fixation Commission Act, 2006}

Water Supply Tariff Fixation Commission (WSTFC) is established for the protection of the interests of consumers by pro viding qualitative and reliable water supply and sanitation service to the consumers at a reasonable price, by fixing the tariff of water supply and sanitation service. WSTFC act is enacted by the House of Representatives in the First year of the issuance of the Declaration of the House of Representatives 2063 (2006). 
The Commission is an autonomous and corporate body with perpetual succession. The Commission comprises of one Chairperson and two Members, appointed by the Government of Nepal. The Commission fixes the tariff for the service, as the service provider may collect from the users. The Commission approves such policies and procedures as to be followed by the service provider in making an application to the Commission for the fixation of tariff. The Commission maintains, or causes to be maintained the quality of service by monitor in $g$ the service to be provided by the service provider. The Commission resolves, or causes to be resolved, disputes arising between the service provider and the users. The Commission obtains statements related with the service provided by the service provider and publish, or caused to be published, the same.

\section{The}

Commission determines criteria on the fixation of $\mathrm{t}$ ariff and cause such criteria to be implemented. The Commission gives necessary advice and suggestion to the Government of Nepal in relation to the water supply or sanitation service, and performs such other functions as prescribed.

Following are the functions, duties and powers of the Commission

- To fix the tariff for the service, as the service provider may collect from the users,

- To approve such policies and procedures as to be followed by the service provider in making an application to the Commission for the fixation of tariff,

- To maintain, or cause to be maintained the quality of service by monitoring the service to be provided by the service provider,

- To resolve, or cause to be resolved, disputes arising between the service provider and the users,

- To obtain statements related with the service provided by the service provider and publish, or caused to be published, the same,

- To determine criteria on the fixation of tariff and cause such criteria to be implemented,

- To give necessary advice and suggestion to the Government of Nepal in relation to the water supply or sanitation service

\section{National Management Information Project (NMIP), 2014}

Since 2006, National Management Information Project (NMIP) has engaged in surveying on coverage and functionality of water supply and sanitation services in Nepal. Besides the survey works at fields, NMIP is constantly taking a lead role and responsibility on updating, managing, analyzing and disseminating the Water and Sanitation sector information.

The development of NMIP survey guideline, detailed survey of 2008, establishment of NMIP database system and the 2010 national report on coverage and functionality of water supply and sanitation services are the milestone of the sector. Besides the coverage status, the first NMIP survey exposed the real scenario of functionality of water supply services in Nepal. Prior to this survey, in comparison with coverage, functionality was not in prime concern among the sector development society. However, the activity of NMIP has successfully drawn and equal attention between functional concerns of built system and the development of new schemes. The NMIP report has highlighted the coverage status and functionality issues of water supply and sanitation services.

The recommendations made in NMIP are still relevant. What is needed further is to align proportionate resource allocation strategically according to the prevailing status. To achieve the national goal of basic water and sanitation facility for all by 2017, a coordinated approach and optimum use of resources together with mobilization of all concerned stakeholders are necessary.

\section{METHODOLOGY}

\section{Nature and Source of Data}

The secondary data was collected from censuses, information collected by government departments, organizational records, published journals, article, and research paper. The schematic flow chart of water supply project has been drawn from the official documents provided by WSUC and RMSO, Dhankuta.

i) Primary Data: Key Informant Interview: - The interview was taken with 4 members of WSUC, 2 WSUC staff, 3 staff from RMSO office. The interview was also conducted with 6 consumers of the service area. The KII was done to find out the managerial aspects, revenue collection, technical matters, operation and maintenance policies, consumer satisfaction Focused Group Discussion was also done.

\section{Secondary Data Collection}

Secondary data were collected for a purpose which was relevant and utilized for the research of study of the project. The data were collected from the detailed engineering project design report, published journals, published article, different websites, Government Agencies. Others are financial report of WSUC, Research paper on key issues of $\mathrm{O} \& \mathrm{M}$, Factors affecting performance are reviewed. The major agencies consulted for collection of secondary data were:

- Central Bureau of Statistics

- Ministry of Water Supply and Sanitation

- Department of Water Supply and Sewerage

- Regional Monitoring and Supervision Office, Dhankuta 
- Water Supply and Sanitation Users Committee, Dhankuta

- Dhankuta Municipality

\section{DATA ANALYSIS}

\section{Financial Performance Indicator}

The financial performance indicator helps to analyze the data related to financial capability of Dhankuta 7, 8, 9 water supply systems.

\section{Water Accounting System}

Water accounting system deals with 3 steps i.e identify revenue re quirements, determine cost of service and design rate structure.

\section{Non-Revenue Water}

The water which is not billing is calculated by following formula.

$$
\operatorname{NRW}(\%)=\frac{\left[\text { Total annual production }\left(\mathrm{m}^{3}\right)\right]-\left[\text { Total bill consumption }\left(\mathrm{m}^{3}\right)\right]}{\left[\text { Total annual production }\left(\mathrm{m}^{3}\right)\right]} \times 100
$$

\section{Average Tariff}

The average tariff is one measure of the financial discipline of a service provider and its ability to cover operational costs with revenues from tariffs with prudent expenditures.

$$
\text { Average tariff }\left(\mathrm{NRs} / \mathrm{m}^{3}\right)=\frac{[\text { Total annual billing(NRs) }]}{\left[\text { Total annual production }\left(\mathrm{m}^{3}\right)\right]}
$$

\section{Personnel Cost}

Personnel costs show the ratio of the salaries of the staff to the total operating costs. It is determined by using following formula.

Personnel cost $(\%)=\frac{\text { Total annual cost in salaries } \times 100}{\text { Total operating cost }}$

\section{Unit Production Cost}

The cost of production for 1000 litre of water is calculated by using following formula.

\section{Operating Ratio}

$$
\text { Unit Production Cost }\left(\mathrm{NRs} / \mathrm{m}^{3}\right)=\frac{[\text { Annual O \& M cost }(\mathrm{NRs})]}{\left[\text { Total annual production }\left(\mathrm{m}^{3}\right)\right]}
$$

The operating ratio is calculated by using following formula.

$$
\text { Operating Ratio }\left(\mathrm{NRs} / \mathrm{m}^{3}\right)=\frac{[\text { Annual O \& M cost }(\mathrm{NRs})]}{\left[\text { Total annual billing }\left(\mathrm{m}^{3}\right)\right]}
$$

\section{Accounts receivable equivalent}

This indicator is good measure of the effectiveness of a service provider in collecting its receivables or bill payments.

Account receivable equivalent $=$

[Accounts receivable(NRs) at end of the fiscal year]

[Total annual Revenue (NRs)/12]

\section{Revenue Collection Efficiency}

This indicator together with average tariff, operating ratio and accounts receivable have impacts on the financial health of a service provider.

Revenue collection efficiency $=$

[Total annual revenue (NRs)] x 100

[Total annual billings (NRs)]

\section{Cash Balance}

The cash balance of the water supply system can be analyzed through net remaining cash on end of each fiscal year.

\section{Pay Back Period}

The payback period of cost of newly constructed reservoirs was analyzed by considering demand and supply, cost estimates of new reservoirs at $15 \%$ NRW, $0 \%$ NRW and national average $21.6 \%$ NRW. This will also help to identify whether there is deficit or surplus of water supply.

\section{Financial Performance}

Financial performance is one of the major parameter for the efficient water supply system. The project is completed with expectation of good return in future. The financial capability of the system is analyzed through water accounting system, non-revenue water, average tariff, personnel cost, unit production 
cost, operating ratio, accounts receivable equivalent, revenue collection efficiency and cost recovery. The measure source of income was water tariff, new connection of private taps in this system.

\section{Water Accounting System}

Water accounting system deals with 3 steps that is identify revenue re quirements, determine cost of service and design rate structure.

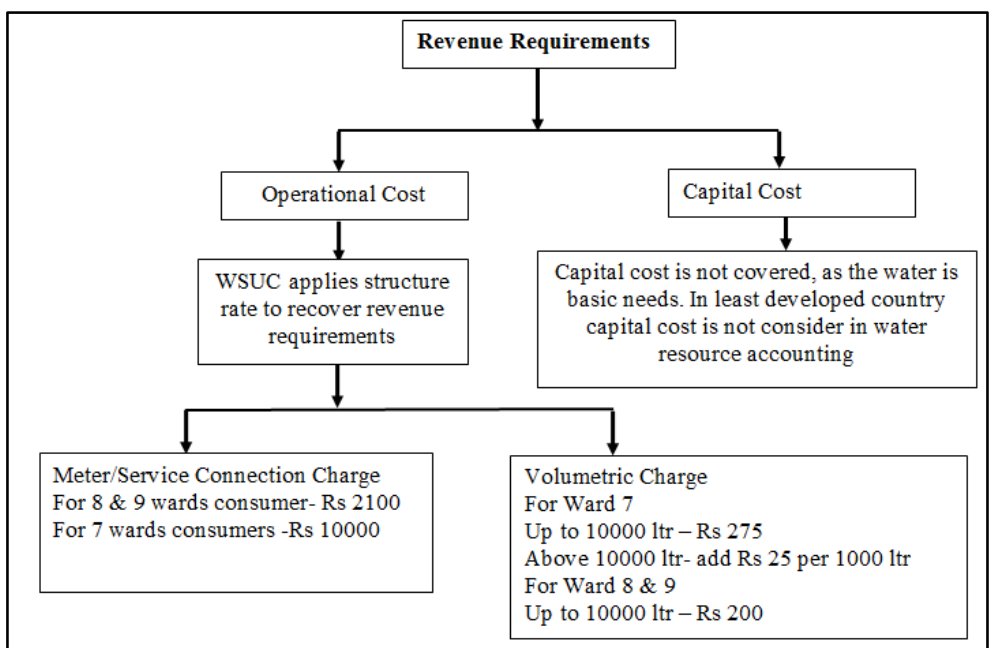

Fig-1: Water Accounting System

(Source: DWSUC, 2016)

The water accounting system for a single system is different which should be uniform. During FGD it was found that the nearby household was misusing the public tap. It remained opened after its use that would result in huge loss of water. Certain area is facing high scarcity and the nearby households were misusing the water which did not seems fair so conflict may arise and the availability of water should be uniform. During field observation it was also found true.

\section{Non-Revenue Water}

The water which is not billing is calculated by following formula.

\section{$\operatorname{NRW}(\%)=\left[\right.$ Total annual production $\left.\left(\mathrm{m}^{3}\right)\right]-\left[\right.$ Total bill consumption $\left.\left(\mathrm{m}^{3}\right)\right] \times 100$ \\ [Total annual production $\left(\mathrm{m}^{3}\right)$ ]}

Table-1: Calculation of Non-Revenue Water

\begin{tabular}{|l|c|c|}
\hline Year & $\mathbf{2 0 1 3 / 1 4}$ & $\mathbf{2 0 1 4} / \mathbf{1 5}$ \\
\hline Total Annual Production & 93312.00 & 93312.00 \\
\hline Total Bill Consumption & 34780.94 & 35168.57 \\
\hline NRW & 62.73 & 62.31 \\
\hline
\end{tabular}

(Source: - DWSUC, 2016)

The average of NRW was found $62.73 \%$ and $62.31 \%$ in FY 2013/14 and FY 2014/15 respectively. The water used for cleaning of reservoirs, Distribution chamber is $0.21 \%$. Out of the total supply in the system $62.31 \%$ of water is not billing which is a serious concern on performance of this system. The national average is only $21.6 \%$. The system is running as there is sufficient quantity of water at source otherwise only minimum population was benefitted. During field observation it was found that there were large cracks and leakage from the stone masonry reservoirs located at each service wards. During KII it was suggested to replace with new ones.

\section{Average Tariff}

The average tariff is calculated as

$$
\text { Average tariff }\left(\mathrm{NRs} / \mathrm{m}^{3}\right)=\quad \frac{[\text { Total annual billing(NRs)] }}{\left[\text { Total annual production }\left(\mathrm{m}^{3}\right)\right]}
$$

Table-2: Calculation of Average Tariff

\begin{tabular}{|l|c|c|}
\hline Year & $\mathbf{2 0 1 3 / 1 4}$ & $\mathbf{2 0 1 4 / 1 5}$ \\
\hline Total Annual Billing & 791600.00 & 789200.00 \\
\hline Total Annual Production & 93312.00 & 93312.00 \\
\hline Average Tariff & 8.48 & 8.46 \\
\hline
\end{tabular}


(Source: - DWSUC, 2016)

The average tariff was found to be Rs $8.46 / \mathrm{m}^{3}$ in $2014 / 15$ which was decreased by $0.02 / \mathrm{m}^{3}$ than in 2013/14. The national average for average tariff is Rs $15.4 / \mathrm{m}^{3}$. The obtained tariff is nearly $50 \%$ less than the national average which indicates that with such low tariffs, Dhankuta 7, 8, 9 water supply systems is not able to cover Operation \& Maintenance costs. During FGD it was found that the consumers are not willing to pay tariff due to unavailability of water on time and they were not satisfied with tariff rate because they were paying the minimum tariff eventhough they did not get the water as required. If the availability of quality water would be confirmed for $24 \mathrm{hr}$ then they were ready to pay as per decision of WSUC.

\section{Personnel Cost}

Personnel costs show the ratio of the salaries of the staff to the total operating costs.

Personnel cost $(\%)=\underline{\text { Total annual cost in salaries } \times 100}$

Total operating cost

Table-3: Calculation of Personnel Cost

\begin{tabular}{|c|c|c|}
\hline Year & $\mathbf{2 0 1 3 / 1 4}$ & $\mathbf{2 0 1 4} / \mathbf{1 5}$ \\
\hline Salary & 318000 & 394000 \\
\hline Operating Cost & 493385 & 598033 \\
\hline Personnel Cost & 64.45 & 65.88 \\
\hline
\end{tabular}

(Source: DWSUC, 2016)

The personnel costs in 2013/14 are $64.45 \%$ whereas it was $65.88 \%$ in $2014 / 15$. The salary of staff was increased resulting increase in personnel cost. The SPI indicated that there was decrease in staff productivity but the increment in salary resulting increment in personnel cost indicated that the financial performance is not good. It was fair to increase the salary if the SPI was decreased. This indicated that there is lack of efficiency of WSUC deciding for increment in salary for lesser staff productivity.

\section{Unit Production Cost}

The cost of production for 1000 litre of water is calculated as

$$
\text { Unit Production Cost }\left(\mathrm{NRs} / \mathrm{m}^{3}\right)=\frac{[\text { Annual O \& M cost }(\mathrm{NRs})]}{\left[\text { Total annual production }\left(\mathrm{m}^{3}\right)\right]}
$$

Table-4:- Calculation of Unit Production Cost

\begin{tabular}{|l|r|r|}
\hline Year & \multicolumn{1}{|c|}{$\mathbf{2 0 1 3 / 1 4}$} & \multicolumn{1}{|c|}{$\mathbf{2 0 1 4 / 1 5}$} \\
\hline Annual O \& M cost (NRs) & 493385.00 & 598033.00 \\
\hline Total annual production (cum) & 93312.00 & 93312.00 \\
\hline Unit Production Cost & 5.29 & 6.41 \\
\hline
\end{tabular}

(Source: DWSUC, 2016)

The unit production cost of Dhankuta WSSP is 5.29 in year 2013/14 whereas there is increment in unit production cost in $2014 / 15$ and reaches up to 6.41 . This showed that the cost of production per 1000 litre is increased by 1.21 due to increase in $\mathrm{O} \& \mathrm{M}$ cost. There was increase in $O \& M$ cost but the system was not providing water as per consumer demand which did not seem fair. As per FGD Operation and maintenance is not satisfactory due to unavailability of water timely.

\section{Operating Ratio}

The operating ratio is calculated as below.

$$
\text { Operating Ratio }\left(\mathrm{NRs} / \mathrm{m}^{3}\right)=\frac{[\text { Annual O \& M cost }(\mathrm{NRs})]}{\left[\text { Total annual billing }\left(\mathrm{m}^{3}\right)\right]}
$$

Table-4.9: Calculation of Operating Ratio

\begin{tabular}{|c|c|c|}
\hline Year & $2013 / 14$ & $2014 / 15$ \\
\hline Annual O \& M cost (NRs) & 175385.00 & 204033.00 \\
\hline Total annual billing (cum) & 34780.94 & 35168.57 \\
\hline Operting Ratio & 5.04 & 5.80 \\
\hline
\end{tabular}

(Source: DWSUC, 2016) 
The operating ratio in the year 2013/14 is 5.04 which is increased and reaches up to 5.8 in the year 2014/15. A low operating ratio means revenues from tariffs (water consumption billings) cover the operation and maintenance costs comfortably. The ratio is higher than the national average which is 1.02 which indicates that the system does not cover $\mathrm{O} \& \mathrm{M}$ cost efficiently.
During FGD the consumer are not willing to pay the tariff due to unavailability of water timely.

\section{Accounts Receivable Equivalent}

This measures the effectiveness of a service provider in collecting its receivables of bill payments. In this case, the receivables are expressed in equivalent of the utility's average monthly billing.

Account receivable equivalent $=[$ Accounts receivable $(\mathrm{NRs})$ at end of the fiscal year $]$

[Total annual Revenue (NRs)/12]

Table-5: Calculation of Accounts Receivable Equivalent

\begin{tabular}{|l|c|c|}
\hline Year & $2013 / 14$ & $2014 / 15$ \\
\hline Accounts Receivable & 35000.00 & 49000.00 \\
\hline Total Annual Revenue & 441000.00 & 578000.00 \\
\hline Accounts Receivable Equivalent & 0.95 & 1.02 \\
\hline
\end{tabular}

(Source: DWSUC, 2016)

The accounts receivable equivalent in 2013/14 and $2014 / 15$ is 0.95 and 1.02 respectively. The national average is 1.4 month. Eventhough it is less than national average it indicated that the receivable are not collected timely in a month. This was due to dissatisfaction of consumer due to unavailability of water timely and delay in operation and maintenance work as per their complain.

\section{Revenue Collection Efficiency}

This indicator together with average tariff, operating ratio and accounts receivable have impacts on the financial health of a service provider.

\section{Revenue collection efficiency $=\quad$ [Total annual revenue (NRs) $] \times 100$ \\ [Total annual billings (NRs)]}

Table-6: Calculation of Revenue Collection Efficiency

\begin{tabular}{|l|r|r|}
\hline Year & $\mathbf{2 0 1 3 / 1 4}$ & \multicolumn{1}{|c|}{$\mathbf{2 0 1 4 / 1 5}$} \\
\hline Total Annual Revenue (NRs) & 441.00 & 578.00 \\
\hline Total Annual Billing (NRs) & 791.60 & 789.20 \\
\hline Revenue Collection Efficiency & 55.71 & 73.24 \\
\hline
\end{tabular}

(Source: DWSUC, 2016)

The revenue collection in the year $2014 / 15$ has been increased to $73.24 \%$ in comparison to the 2013/14 which is only $55.71 \%$. The generated revenue is less in regards with national average which is $98.6 \%$. The less revenue collection efficiency has great impact on financial capability of service provider. The service provider should increase their collection efforts and encourage consumers to pay their bills on time. During
FGD it was found that the consumer is not motivated to pay the bill on time because they do not get water as per their demand and the availability of water is only 6hrs.

\section{Cash Balance}

The cash balance of five continuous fiscal year from $2010 / 11$ to $2014 / 15$ is shown in Table 7.

Table-7: Cash Balance

\begin{tabular}{|c|c|c|c|c|c|}
\hline Fiscal Year & $\mathbf{2 0 1 0 / 0 1 1}$ & $\mathbf{2 0 1 1 / 0 1 2}$ & $\mathbf{2 0 1 2 / 0 1 3}$ & $\mathbf{2 0 1 3 / 0 1 4}$ & $\mathbf{2 0 1 4 / 0 1 5}$ \\
\hline Income (Rs) & 349838 & 424324 & 624734 & 621067 & 877606 \\
\hline Operating Expenditure (Rs) & 271099 & 299692 & 458994 & 493385 & 598034 \\
\hline Balance (Rs) & 78739 & 124632 & 165740 & 127682 & 279572 \\
\hline
\end{tabular}

(Source: DWSUC, 2016)

The income in the FY 2010/11 is NRs 349838 which increases and reaches up to NRs 877606 in the Year 2014/15 whereas the remaining balance after operating expenses in the year 2010/11 and 2014/15 is NRs 78739 and NRs 279572 respectively. It is clearly seen that the income is in increasing trend resulting in increased operating expenditure along with increased balance. The rate of increment is higher than that of expenditure. The cash balance at $2012 / 13$ is NRs 165740 which then decreased and reaches NRs 127682 at the end of FY 2013/14. In 2014/15 there is increment in balance more than double than that is 2013/14 which is NRs 279572. The increment in cash balance shows that the water supply system is increasing income and 
reducing the $\mathrm{O} \& \mathrm{M}$ cost which indicates that the system is promoting towards its own capability. The result shows that the supply of $28.27 \%$ of water is generating positive cash flows even though there is $62.31 \% \mathrm{NRW}$. If the NRW is controlled then there is more increment in positive flow of cash balance which will make the system financially more viable.

\section{Pay Back Period}

The payback period is calculated through following analysis

\section{Demand and Supply}

\begin{tabular}{|c|c|c|c|c|c|c|c|c|}
\hline $\begin{array}{l}\text { Benifitted } \\
\text { Household }\end{array}$ & $\begin{array}{c}\text { Served } \\
\text { Population }\end{array}$ & $\begin{array}{c}\text { Percapita } \\
\text { demand as per } \\
\text { urbanization } \\
\text { (Litre per day) }\end{array}$ & $\begin{array}{c}\text { Total } \\
\text { Demand } \\
\text { Monthly } \\
\text { (cum) } \\
\end{array}$ & $\begin{array}{c}\text { Available } \\
\text { Source } \\
\text { Monthly } \\
\text { (Cum) }\end{array}$ & $\begin{array}{c}\text { Total } \\
\text { Distribution } \\
\text { Monthly } \\
\text { (Cum) } \\
\end{array}$ & $\begin{array}{c}\text { Total } \\
\text { Billing } \\
\text { Monthly } \\
\text { (Cum) } \\
\end{array}$ & $\begin{array}{l}\text { Existing } \\
\text { Supply }\end{array}$ & $\begin{array}{l}\text { Difference } \\
\text { of Surplus } \\
\text { (Cum) }\end{array}$ \\
\hline 349 & 1910 & 100 & 5730 & 7776 & 7760 & 2960.18 & $6 \mathrm{Hrs}$ & 2046.00 \\
\hline $\begin{array}{l}\text { Benifitted } \\
\text { Household }\end{array}$ & $\begin{array}{c}\text { Served } \\
\text { Population }\end{array}$ & $\begin{array}{c}\text { Percapita } \\
\text { demand as per } \\
\text { urbanization } \\
\text { (Litre per day) }\end{array}$ & $\begin{array}{c}\text { Total } \\
\text { Demand } \\
\text { Monthly } \\
\text { (cum) }\end{array}$ & $\begin{array}{c}\text { Available } \\
\text { Source } \\
\text { Monthly } \\
\text { (Cum) }\end{array}$ & $\begin{array}{c}\text { Total } \\
\text { Distribution } \\
\text { Monthly } \\
\text { (Cum) }\end{array}$ & $\begin{array}{c}\text { Total } \\
\text { Billing } \\
\text { Monthly } \\
\text { (Cum) }\end{array}$ & $\begin{array}{l}\text { Existing } \\
\text { Supply }\end{array}$ & $\begin{array}{l}\text { Difference } \\
\text { of Surplus } \\
\text { (Cum) }\end{array}$ \\
\hline 349 & 1910 & 100 & 5730 & 7776 & 7760 & 2960.18 & $6 \mathrm{Hrs}$ & 2046.00 \\
\hline
\end{tabular}

The current benefitted household was 349 with 1910 population. Considering $100 \mathrm{lpcd}$ as per capita demand for urbanization area the total demand of a month was 5730 cum. The source consists of $3 \mathrm{l} / \mathrm{s}$ discharge which was 7776 cum in a month. After deducting $0.21 \%$ of the water for cleaning purpose of water supply structures during flushing the distribution was 7760 cum monthly. The billing of water was found $38.14 \%$ of total distribution which was 2960.18 cum per month. The supply of water was only 6 hour in a day. Due to availability of sufficient water at source the system is running eventhough there is high non-revenue water. The water demand is lesser with 2046 cum than that in the source showing surplus of water which could be distributed for further expansion of water supply system. During FGD it was found that the ward no 8 and ward no. 9 population still need to be served with the water supply system after repair and maintenance work. There is huge gap in distributed volume and total billing volume that showed high volume of water as non-revenue water.

\section{Cost Estimate for Reconstruction of Reservoirs}

Table-8: Cost Estimates

\begin{tabular}{|c|c|c|c|c|}
\hline S.No. & Description & Condition & Requirements & Amount \\
\hline \multirow[t]{4}{*}{1} & Reservoir Tanks (Ward 7) & & & \\
\hline & Ferrocement Tank-20 cum & Good & & \\
\hline & Stone Masonary-12 cum & Bad & FCRT-12 cum & 264000 \\
\hline & Stone Masonary-75 cum & Bad & RCC-75 cum & 1450000 \\
\hline \multirow[t]{7}{*}{2} & Reservoir Tanks (Ward 8) & & & \\
\hline & Ferrocement Tank-6 cum & Good & & \\
\hline & Ferrocement Tank-14 cum & Good & & \\
\hline & Ferrocement Tank-10 cum & Good & & \\
\hline & Stone Masonary Tank-35 cum & Bad & RCC- 35 cum & 1275000 \\
\hline & Stone Masonary Tank-20 cum & Bad & FCRT- 20 cum & 326000 \\
\hline & Stone Masonary Tank-25 cum & Bad & RCC - 25 cum & 1025000 \\
\hline \multirow[t]{6}{*}{3} & Reservoir Tanks (Ward 9) & & & \\
\hline & Ferrocement Tank- 6 cum & Good & & \\
\hline & Ferrocement Tank- 20 cum & Good & & \\
\hline & Stone Masonary Tank- 35 cum & Bad & RCC - 35 cum & 1275000 \\
\hline & Fittings and Tools & & Require Fittings & 300000 \\
\hline & Total & & & 5915000 \\
\hline
\end{tabular}

The physical structure index showed that physical status of stone masonry reservoirs was bad whereas the ferrocement tank is functioning properly. During the FGD and field survey it was found that the stone masonary reservoir tank should be replaced with new reservoir due to their heavy leakage from cracks at bottom and walls. The KII as Engineer from RMSO suggest that the maintenance cost and reconstruction cost will be near so the long term solution would be to dismantle and construct new reservoirs. The tentative 
cost estimate as the information provided by Engineer from RMSO for construction of new reservoirs Pay Back Period

The loss of leakage, flush back are assumed to be $15 \%$ and the payback period of cost needed for reservoir reconstruction is shown in table 9 .

Table-9: Pay Back Period

\begin{tabular}{|l|c|c|c|}
\hline & NRW=15 \% & NRW=0\% & NRW=21.6\% \\
\hline Total Source Available (cum) & 7776.00 & 7776.00 & 7776.00 \\
\hline Wastage Unit as NRW & 1166.40 & 0.00 & 1679.62 \\
\hline Remaining Volume (cum) & 6609.60 & 7776.00 & 6096.38 \\
\hline Cost of each Unit (10000) NRs. & 275 & 275 & 275 \\
\hline Total Revenue in Month NRs. & 181764 & 213840 & 167650.56 \\
\hline Total Yearly Revenue in NRs & 2181168 & 2566080 & 2011806.72 \\
\hline & & & \\
\hline Cost of New Reservoirs & 5915000 & 5915000 & 5915000 \\
\hline Cost of O \& M & 717640.80 & 717640.80 & 717640.80 \\
\hline Pay Back Period & 3.04 & 2.58 & 3.30 \\
\hline
\end{tabular}

The tapped water from source is $3 \mathrm{l} / \mathrm{s}$ which is $7776 \mathrm{cum} / \mathrm{month}$. Considering the flush back system and minor leakage as $15 \%$ of water then the remaining water would be $6609.6 \mathrm{cum} / \mathrm{month}$ for distribution that would generate revenue NRs 2181168 for unit cost as NRs 275. Considering the cost of reservoirs and cost of operation and maintenance the payback period was calculated as 3 year half month. Similarly for NRW at $0 \%$ and NRW for national average $21.6 \%$ (SEIU, 2015) the payback period was found to be 2 year 7 month and 3 year 4 month respectively.

In general the payback period of the water supply system is 15-20 years so for this system the investment in reconstruction of reservoirs would be able to provide $24 \mathrm{hrs}$ supply of water as per their demand for existing household and the analysis shows that cost is recovered in few years. As the source is sufficient so the expansion of system for reaching the unreached population in the command area could be done which ultimately would be beneficial for early recovery of investment.

The key findings regarding to assessment of financial performance are as follows

- There is dissimilarity in tariff rate on water accounting system.

- The non-revenue water is $62.31 \%$ resulting large sum of revenue loss

- The average tariff is NRs $8.46 / \mathrm{m}^{3}$ which will not be able to cover $\mathrm{O} \& \mathrm{M}$ costs

- The personnel cost is $65.88 \%$ due to increment in salary of staff's even though SPI is less.

- The unit production cost is NRs 6.41 per 1000 litre resulting increase in $\mathrm{O} \& \mathrm{M}$ costs.

- The operating ratio 5.8 indicates that the billing does not cover $\mathrm{O} \& \mathrm{M}$ cost comfortably.

- Accounts receivable equivalent is 1.02 months which shows the consumer do not pay tariff on time.
- The revenue collection efficiency $73.24 \%$ which indicates that the service provider should increase collection effort and emphasis on supply management.

- There is positive cash balance in five continuous fiscal year.

- The payback period is 3 year half month, 2 year 7 month and 3 year 4 month for 15\% NRW, 0\% NRW and $21.6 \%$ NRW respectively.

\section{CONCLUSION}

The generation of positive cash flow in each fiscal year shows that the financial performance is well. The system could be made more effective after maintenance work which will create willingness for consumer to pay the bill on time, that will eventually generate more revenue and the system could be financially more viable.

\section{REFFEREFENCE}

1. Brikke, F. (2000). Operation and Maintenance of rural water supply and sanitation systems. A training package for managers and planners. Malta: IRC International Water and Sanitation Centre and World Health Organization, [Online]. Available at: http://www.who.int/water_sanitation_health/hyg iene/om/Rural-intro.pdf. [Accessed 15 October 2014].

2. Danilenko, A., Berg, C., Macheve, B., Moffitt, L.J. (2014). The IBNET Water Supply and Sanitation Blue Book 2014, [Online]. Available at: https://openknowledge.worldbank.org/bitstream/ha ndle/10986/19811/9781464802768.pdf. [Accessed 28 September 2014].

3. Mishra, A.K., (2018). International Journal of Operations Management and Information Technology. 8(1), 1-30 (c) Research India Publications http://www.ripublication.com 
4. Mishra, A.K., Karna, A.K., Dhakal, N. (2019). Assessment of Performance of Functional and Partial Functional Water Supply Systems in Sunsari District of Nepal. J Adv Res HR Organ Mqmt, 6(1): 1-15.

5. Mishra, A.K., Acharya, S.R.(2018). Performance Assessment of Salyankot Water Supply Project in Post-Earthquake Scenario of Nepal. J Adv Res GeoSci Rem Sens, 5(3,4): 23-40.

6. Mishra, A. K.(2018). Sustainability and Risk Assessment of Salyankot Water Supply Project in Post-Earthquake Scenario. International Journal of Operations Management and Information Technology, 8(1): 1-30. Available at http://www.ripublication.com.

7. Mishra, A.K, Karna, A.K. (2019). "Assessment of Management Transfer Process of Water Supply Systems in Sunsari District of Nepal." International Journal of Research Granthaalayah, 7(1): 1-24.

8. DWSS. (2011). Nationwide Coverage and Functionality Status of Water Supply and Sanitation in Nepal, 2011. Kathmandu, Nepal: National Management Information Project, Department of Water Supply and Sewerage (DWSS).

9. MOPPW. (2004). Rural Water Supply and Sanitation National Policy, 2004. Kathmandu, Nepal: Ministry of Physical Planning and Works (MOPPW).

10. MOPPW. (2004). Rural Water Supply and Sanitation Strategic Action Plan, Kathmandu, Nepal: Ministry of Physical Planning and Works (MOPPW).

11. MOPPW. (2009). Urban Water Supply and Sanitation National Policy, 2009. Kathmandu, Nepal: Ministry of Physical Planning and Works (MOPPW).
12. NEWAH, Website. Cross Cutting Themes, [Online]. Available at: http://newah.org.np/index1.php?option=informatio n\&id=28 [Accessed 16 August 2014].

13. NPC. (2071). Thirteenth Plan (Fiscal Year 2070/71-2072/73, 2071. Kathmandu, Nepal: Government of Nepal, National Planning Commission (NPC).

14. WB. (2009a). The Capacity Development Results Framework: A strategic and results-oriented approach to learning for capacity development, [Online]. Available at: http://siteresources.worldbank.org/CSO/Resources/ 228716-1369241545034.pdf. [Accessed 28 September 2014].

15. WB. (2009b). Water Operators Partnership-Africa Utility Performance Assessment. [Online]. Available http://www.wsp.org/sites/wsp.org/files/publications /WOP_Report.pdf. [Accessed 02 October 2014].

16. WB.(2010). Sustainable Management of Small Water Supply Systems in Africa, Practitioners' Workshop Report, October 6-8, 2010 [Online]. Available at http://www.wsp.org/sites/wsp.org/files/publications /Sustainable_Management_of_small_water_supply _systems_in_Africa_English.pdf. [Accessed 15 August 2014].

17. WB. (2012). Guide to Evaluating Capacity Development Results, [Online]. Available at: https://wbi.worldbank.org/wbi/Data/wbi/wbicms/fil es/drupalacquia/wbi/Guide\%20to\%20Evaluating\%20Capaci ty\%20Development\%20Results_0.pdf. [Accessed 28 September 2014].

18. WECS. (2005). National Water Plan, 2005. Nepal: Ministry of Water Resources, Water and Energy Commission Secretariat (WECS). 